\title{
ENREGISTERING THE VOICES OF DISCURSIVE FIGURES OF AUTHORITY IN ANTONERO CHILDREN'S SOCIO-DRAMATIC PLAY
}

\author{
Jennifer F. Reynolds
}

\begin{abstract}
This study examines how boys from San Antonio Aguas Calientes, Guatemala develop their own perspective about what it means to be moral human beings in the world via discursive practices that contrast enregistered voices within an emergent performance genre that simultaneously doubles as sociodramatic play-frame. This emergent genre exhibits both mimesis and alterity; children have appropriated a popular adult genre, within which their participation, originally, was highly circumscribed. In their own productions, however, they occupy the main character roles and enact re-accented "voices" of king and kin in highly competitive, proselytizing discourse. The resulting performance is a subversion of the social order where 'the challenge' of good defeating evil is undone, reflecting a child-centric critical stance. To wit, the boys refuse to be convinced by the authority of an overly patriarchal-colonial moral order. I build upon Sawyers' (1995) model of play-as-improvisation to develop a synthetic framework in analyzing indigenous children's play and childhood(s). The approach I espouse draws upon ethnographically informed studies of peer talk-in-interaction, verbal art as performance, and semiotic functionalism to examine how children "do heteroglossia" in and out-of-play frames of interaction as they construct selves capable of confronting the social order.
\end{abstract}

Keywords: Voicing contrasts; Enregisterment; Verbal art as performance; Socio-dramatic play; Kaqchikel Maya children.

\section{Introduction}

In the Kaqchikel Maya town of San Antonio Aguas Calientes, Guatemala, town members annually enact el Desafío 'the Challenge', a set of weekly street performances that begin, following the Catholic Church calendar, on January 20th in celebration of el niño, dulce nombre de Jesus 'the sweet name of baby Jesus'. Desafío performances commemorate the 1492 Spanish reconquest of the Iberian Peninsula. The central plot of this genre pits el Rey Cristiano 'the Christian King' and el Rey Moro 'the Moorish King' against each other in battle. It likewise exhibits a moral binary framework where "good" Christians ultimately triumph over "evil” non-Christian others (i.e. Muslims) and convert them to Christianity. Many children of San Antonio elaborate this genre for months thereafter in socio-dramatic play. Boys and girls don homemade costumes of capes, crowns, newspaper wigs, ride stick-horses, brandish swords, and improvise royal speeches in order to enact their performance genre called, Rey Moro 'Moorish King'.

Scholarship in linguistic anthropology, child-centered discourse analysis, cultural psychology and the sociology of childhood privilege children's narratives and play (especially pretend play) as important sites of peer socialization and development 
as well as the elaboration of peer culture. A subset of these approaches highlights the multiple dimensions of language as a symbolic, ideological, and pragmatic system in the organization and socialization of peer culture. Children and youth are arbiters of communicative competence when they socialize each other to use language(s) (All contributors, this volume; Paugh 2005) and ways of speaking, including speech registers (Ervin-Tripp 1977; Kyratzis, Max and Wade 2001), speech styles (Cook-Gumperz 1995), and activity types and genres (Bauman 1982; de León 2006; Minks 2008; Reynolds 2008, 2010). These traditions emphasize different levels of analysis - from the ontogenetic development of individual children to the socio-historical emergence of peer culture and child-centric speech genres, including children's voices keying persona from different social domains (Cf. Sawyer 2001, 2003 for a discussion of these different levels of analysis).

This article examines how the emergence of a child-centric speech genre is inextricably intertwined with children's manipulation of voice. In the literature, "voice" has been variously treated. All agree that it serves a metacommunicative function, a framing device that children often employ to shift between frames of interaction (Bateson 1972; Hoyle 1998; Sawyer 2003; Wolf and Hicks 1989). Discourse analysts, Wolf and Hicks (1989) have defined voice as "a stance taken by the speaker relative to the unfolding narrative events" (1989: 335). Children assume their "real” voices or an executive voice of stage-manager to contest prior play moves and coordinate future ones during out-of-play frames. In-play-frame voices might include a (third person) narrator and/or in-character participants. Other scholars have focused on voice as the enactment of in-character roles and selves. Voice is keyed by speech style (Cook-Gumperz 1995; Goldman 1989) or code (as language or register)-specific genres (Hoyle 1993, 1998; García-Sánchez this volume; Garrett 2005; Paugh 2005).

Child-centric studies, like other sociolinguistic examinations of voice, have been imprecise in how the concepts of voice, stance, register and even genre are used (Ferguson 1994). In the case of Wolf and Hicks' definition above, voice may be one way to strike a stance, but in discourse, the two operate at different levels. Agha (2005) has critiqued that "voice" is used often interchangeably with "register". And while some voicing contrasts strike stances, not all stances struck in interaction indexically hail stereotypical figures of personhood associated with social registers. Ochs (1992) makes clear that in interaction, unmarked affective and epistemological stances are interpreted pragmatically as direct indices only. It is during ideologically marked occasions of use, that indirect indexicality semiotically conjures up real or imagined types of people who presumably talk and sound like that.

Current theoretical work, moreover, is moving away from analyses of voice understood as a static bundle of stylistic co-occurring features that reifies a single indexical entailment from speaker-to-context toward a Bakhtian framework predicated on the concept of heteroglossia - a dynamic system of stratified diversity (Bakhtin 1981). Voicing phenomena semiotically and ideologically operate in micro-level contingent processes that inform historical changes in register values and generic practices within macro-sociological fields (Pujolar 2000; Agha 2003, 2005; Silverstein 2003). This approach is useful for ethnographic and process-oriented empirical studies that seek to track the discursive resources and practices through which social actors creatively do voicing contrasts to reproduce as well as challenge the social range of speakers imagined to command highly valued language varieties conventionalized as recognizable registers and genre-specific fashions of speaking. Here, I tackle the issue 
of how to interpret children's voicing contrasts across speech chains within an embellished, child-centered work-in-progress. These contrasts potentially index children's multiple positionalities against a shifting ground where the only constant is Rey Moro, a particular moral figure of personhood who captured these children's imaginations.

In the analytic sections of this paper, I situate children's performances within a social history of reconquest performance genres. These genres continue to be germane in social struggles over staking-claims to place(s) and imagining collective belonging throughout Latin America. My discussion entertains sociocultural debates about the ideological work that these local cultural productions achieve as adult-centric expressions of interpretive reproduction. The focus then narrows to examine the significance of a particular token of this type of genre, el Desafío in San Antonio Aguas Calientes, an indigenous Kaqchikel Maya town in the advanced stages of language shift. I detail the cultural script of el Desafío performance plot as well as the ways in which children are able to participate in adult street performances. Following that is an examination of how one network of children participated in the creation of an emergent child-centric performance genre as they simultaneously negotiated and indexed their position of relative powerlessness as members of age-graded, extended kin and peer networks. Particular attention is paid to how different discursive figures of authority emerged through voicing contrasts - in some cases revealing enregistered voices (Agha 2003, 2005) in children's improvised royal speeches. It will be argued that while knowledge of the adult performance script may scaffold the emerging child-centric performance, children's improvised collaborations are heteroglossic performances (Sawyer 1995, 2002), revealing a polyphony of voices that in fact expands the social range of persona who speak in a hybrid authoritative register of kings and kin particular to stylistic variation within this performance genre (Bauman 2001).

\section{Method of inquiry: Ethnographic setting and peer group practices}

This study of Antonero children's collaborative socio-dramatic play is part of a larger ethnographic exploration of child language socialization and the politics of Mayan childhoods in post-civil war Guatemala. The data corpus consists of fieldnotes and video-recordings derived while being a participant observer within San Antonio from March 1998 - March 1999. I had intimate access to daily family rhythms and routines of three extended households comprised of networked handicraft venders. Forty hours of naturally occurring speech of caregiver-child and peer interactions were video-recorded and transcribed. Informal ethnographic interviews with family members and audiorecordings of subjects' evaluations of video-footage were also collected to triangulate the grounded analysis of play activities. In true ethnographic fashion, pseudonyms are used to ensure participant confidentiality.

Maya children's peer cultural practices, which might be considered distinct from "adult" culture, have varied historically within and across diverse ethnolinguistic regions (Nash 1970; de León 2007; Gaskins 2006; Reynolds 2002; Rogoff 1981, 2003). In all of these community contexts young children's peer and kin networks were often one and the same, especially for very young children whose mobility was restricted to the confines of household courtyards. San Antonio networks included other non-kin children and youths from the same neighborhood, from school, and from work in those 
cases where children were handicraft venders. Networks overlapped as children from the neighborhood might have attended the same school. Peer groups were not strictly age-graded though relatively same-age kin played together. Once children started school, they formed friendships with classmates who were also approximately the same age. The greatest range in peers' ages is evidenced in work-based networks where a four-year-old worked alongside teenagers and married women, only some of whom were kin. All three households reflect a diverse range of ages in children's peer networks.

Across households there was variation in children's preferred play activities, and preferences often shifted following seasonal activities. The data for this analysis were derived from three months of observed and recorded Rey Moro socio-dramatic play during the dry season within the third household where the influence of el Desafío was striking; Pedrito Hernandez Pop (six years-old), the host of many performances, displayed an expert ability to recite royal speeches. I observed children from other households enact public processions and performances, including play that resembled $e l$ Desafío. Children had attended local festival performances since infancy and so were intimately familiar with the plot, the characters, and some features of the oratorical style. Few children, however, actually knew the content of Desafío speeches. The masks worn muffle performers' speeches, making it virtually impossible for audience members, including adults, to fully comprehend. Only performers, who had memorized the hand-written scripts passed down from one generation to the next, knew the actual form and content of royal speeches. The expert bias in my data set reflects the fact that Pedrito's older brother, Paco, was a participant in prior Desafío performances. He had spent many a day, sequestered in his bedroom, memorizing and rehearsing speeches. Pedrito was a peripheral participant to many of these sessions and subsequently learned both the form and content of royal speeches. Analyses underscore his pivotal role linking one speech chain network (Agha 2003) of adult Desafío performers to a peer group speech chain network of Rey Moro child actors.

\section{Genres of reconquest - then and now}

Anthropologists and folklorists of Latin American festival genres often attempt to trace their origins to medieval Spain (Bauman 1996). El Desafío, for example, is an instance of genres of reconquest. It dates back to the colonial era when friars first adopted Aztec and other indigenous public performances and imbued them with Catholic Church and Spanish history to teach and facilitate conversion of colonial subjects (Bricker 1973; Harris 2000; Porrúa 1994). Across diverse regions of Middle America, indigenous groups continued these traditions, emphasizing different historical events and characters to re-enact, though many recycled the same set of Christian protagonists (Spanish or French) and "Moor" antagonists (Turks, North Africans, and Jews). Bricker (1973) suggested that antecedents of Desafío-like performance genres were products of early colonial ethno-political alliances.

On June 18, 1539, the emperor of Spain and the king of France signed a peace treaty. To commemorate this event, the Indians and Spaniards of Mexico City staged the conquest of Rhodes. The Tlaxcalans, not to be outdone, staged the conquest of Jerusalem (Steck 1951: 158), this was perhaps the first performance of the religious 
play commonly known as the Battle (or Dance) of the Moors and Christians... (Bricker 1973: 198)

Contemporary anthropological accounts of these and other festival performance genres have emphasized the cultural dialectic of "tradition" in defining indigenous identities across communities networked in migratory circuits, often encompassing a transnational social field (Glick Schiller 2003; Rouse 1991). Historically, different Latin American governments have strategically created folklorized representations of preColumbian peoples in their respective nation-building projects (Canclini 1995; Casteñeda 1996; Nagengast and Kearney 1990; Rogers 1999). In some cases popular street performances accommodated state-sponsored development efforts in tourism, extracting wealth in the commoditization of indigenous and other ethnically marked identities $^{1}$. Such instances, however, do not overshadow the preponderance of community efforts that eschew commercialized venues in order to create a satisfying performance, where intimate audience-performer interactions exert a profound impact on the local social significance of the genre while at the same time affording multiple interpretations (Flores 1994; Limón 1983; Nájera-Ramírez 1999). This is especially true of double-voiced folk genres that incorporate elements of the carnivalesque (Bakhtin 1984). Current scholarship in indigenous communities examines how performers seek to recuperate and valorize ethnic-regional identities via these "spectacular performances" as a means to pressure states to implement socio-economic policies inclusive of all citizens (Goldstein 2004; Cf. Kearney 2000; Nagengast and Kearney 1990 ) and to restore a sense of cultural continuity in the midst of traumatic change and criminal impunity (Offit and Cook 2010). All analyses underscore how the flexible staging of these performance genres permits appropriation for a variety of competing interests, while the formal properties afford the reproduction of "tradition". Each performance is unique and enables the inflection of additional cultural, political and economic significances to reflect shifts in socio-historical contexts, geo-political alignments, and as I argue below, age-graded generational perspectives.

\subsection{El Desafío: Historical background and local cultural significance}

San Antonio Aguas Calientes, located in the central highlands of Guatemala, was established as a multi-ethnic slave colony called Milpa de Juan de Chavez, originally named after the lieutenant to whom the encomienda was granted (Annis 1987). The colonial settlement's diverse population hailed from a variety of ethnolinguistic communities, but the town's location at the center of a Kaqchikel language community shaped the emergence of Kaqchikel as lingua franca.

In modern times, San Antonio was one of the few highland Maya communities where stable Kaqchikel-Spanish bilingualism became the norm. Since the 1970s, during the time of state-sponsored violence, the situation of balanced bilingualism began shifting toward Spanish dominance amongst children and youths (Brown 1998). In the

${ }^{1}$ San Antonio enactments of el Desafío take place during the dry season and attendant audience members are strictly local. The dry season is a time of year when European and U.S. tourism to the region is seasonnaly low. Other highland community festivals do take place during the rainy season and are routinely advertised in tourist brochures designed by INGUAT, the national tourist agency, to promote international tourism in the region. 
1990s during the period of this study, everyone with whom I spoke was aware of this shift, but most were not troubled by it. Only a few families were drawn into Pan-Mayan activism and language revitalization efforts (Warren 1998; French 2010). Most families subscribed to enactive (Hill 1998) and utilitarian ideologies of language (Kroskrity 2000) where language is understood to be an important symbolic tool in enacting relationships and obtaining important resources. From this insider perspective, the local variety of Kaqchikel spoken in San Antonio was not treated as emblematic of a unique ethnic (i.e. Kaqchikel) identity per se, but rather was understood as indexical of one's place-based identity (Reynolds 2009). Amongst handicraft vendors and other entrepreneurs operating in both formal and informal economic sectors, command of Spanish was understood to be necessary, though global English was valorized over all other codes in the popular imaginary.

Despite being a historical product of Spanish colonialism, the people of San Antonio proudly proclaimed a municipal-indigenous identity and considered themselves highly cosmopolitan. One particular reckoning of this logic staked a claim to indigenous residents being the only "true" españoles 'Spaniards'. This counter-hegemonic identification eschewed the dominant perspective that presumed a pseudo-biological ethno-racial theory of blood relations (Casuas Arzú 1992). Instead, it imbued the descendants of the original Antonero inhabitants with a political-moral authority founded upon an historical socio-political alliance between freed slaves and ex-Spanish colonial landowners (Reynolds 2002). The patriarch of the Hernandez Pop family, Don Gabriel shared this perspective with me during a metacommunicative conversation about the local significance of el Desafío. As an indigenous descendent of the true españoles, he embraced the moral authority engendered in the figure of the Christian King.

Catholic parishioners annually sponsor festival events-including el Desafío; town members of all ages participate in fund-raising, securing costumes and horses, performing, and attending performances. Sponsors contribute part of their annual wages in addition to soliciting door-to-door donations. Children are particularly active in the door-to-door phase of fund-raising; sponsors enlist children from their own kin and neighborhood networks to dress up like micos (monkeys) and dance through the streets asking for contributions. In this way, children are contributors in the reciprocal gifting of this performance to the community even though they do not take center stage as performers (Flores 1994).

\subsection{El Desafío - adult public performances}

Desafío public performances comprise a sequence of events that is repeatedly enacted in different parts of the town. Performances commence in the early evening and often conclude late at night when the procession finally reenters the cathedral. Christians astride horses parade through the streets leading the religious procession that houses the image of Christ. The procession halts when it encounters a cavalry of menacing Moors blocking the path. Rey Moro briefly draws near Rey Cristiano and his followers, after which he returns to his side and prepares for the challenge. Rey Cristiano sends his messenger to convince Rey Moro that there is only one true religion, the Christian religion, and invites Rey Moro to accept this faith. Rey Moro responds by rejecting Christianity. The messenger shuttles back and forth between the two kings, delivering 
taunting messages, which denigrate the respective beliefs. The challenge escalates until the two kings meet in battle, cross swords and exchange reciprocal threats and opposing religious proclamations.

The sword fight is fast and furious and the Christian King inevitably vanquishes the Moorish King. This is represented by the placement of Rey Cristiano's sword at the back of Rey Moro's neck. Rey Moro, however, does not die. Together the two performers ride over to the processional float. Rey Cristiano directly addresses a statue of Jesus Christ. Initially, he greets Him and acknowledges His greatness, represented in the power of the palabra (word) to proselytize and convert those who hear and accept it as representing the voice of the one true God. Rey Cristiano then asserts that Christ's greatness is manifest in Rey Moro's submission and admission that Jesus is the son of God, and that this God is a Christian God. There is no verbal acknowledgement that the power of the word rests on the power of the sword, positioned at the back of Rey Moro's neck. Finally, the Christian King invites Rey Moro to address Jesus, deliver his own speech pleading forgiveness and affirm that he is now convinced of Christ's greatness. In the adjacent town of Santa Catarina, Desafío performances are nearly identical with one exception. They refer to Jesus as Señor Esquipulas, after the image of el Cristo Negro 'the Black Christ' located in Esquipulas, Guatemala. El Cristo Negro is one of the most famous representations of Christ in Central America and Mexico and many people make annual pilgrimages to pay their respects. In both community contexts, el Rey Moro always displays obeisance to the figure of Christ and acknowledges Him as the only legitimate God.

\title{
(1) Rey Moro speech from an El Desafío performance
}

\author{
RM; ai::: cie::lo. \\ convencido estoy. \\ (porque) del cielo (??) bajó. \\ es que al fin me contestaron \\ (???) \\ convence todo tus hijos \\ aquella memoria (?) ama(?).
}
RM; ai::: heavens.
Convinced am I.
(because) from the heavens (??) you descended.
finally I received an answer.
[you] convince all your children. [of] that memory (?) love (?).

The performance officially draws to a close when both kings deliver a choral despedida (closing speech) where they thank and take their leave of Jesus (a.k.a. Señor Esquipulas).

After observing five different performances and participating in postperformance evaluative discussions within households, it was clear to me that there were notable variations - especially in performers' interpretations (Cf. Bauman 1996) and competencies. Nevertheless, the binary moral logic of good versus evil remained in tact re-inscribing a patriarchal moral order where the rule of God, much like the rule of the male head of household, is not overtly questioned or challenged. 


\subsection{El Rey Moro: Children's socio-dramatic enactments}

In the observed Rey Moro socio-dramatic enactments, child actors strictly adhered to el Desafío's cast of characters and sequences of events. They often constructed costumes like the ones used in adult performances. If partial costumes were not included, then the children might subsequently discount it as an authentic performance ${ }^{2}$. Children, moreover, used pretend horses, thereby distinguishing their form of play as mimetically enacting el Desafío and not a different public performance known as El Baile de Los Moros 'The Dance of the Moors' that is performed on foot.

El Rey Moro play minimally required two participants to assume the character roles Rey Cristiano and Rey Moro. Children negotiated role assignment to determine who would be kings, who would be the messenger, and who would take part in the procession. These negotiations proceeded with great care so as not to exclude any child. The ages of child participants ranged from 18 months to 12 years of age. Even children who did not know the play sequence of events were outfitted with stick swords and horses if only to act as extras in simulated battles between Christians and Moors. In fact, older children went out of their way to accommodate younger ones; this was in part a reflection of their dual role as peers and caregivers (Reynolds 2008, 2010).

The participants in my Rey Moro data set were overwhelming boys. This was due to the fact that all of the children who resided in the neighborhood block were male. When Pedrito's older siblings visited the household, they brought with them young nieces who would then be incorporated into the socio-dramatic play. Usually there was no significant gendering of children's role assignment - boys and girls both enacted male characters. On one occasion I witnessed Pedrito provisionally change the sex of the king to that of queen in order to elicit the participation of an obstinate Rosie, his four-year-old niece. Pedrito referred to her as the Moorish King, however, in the actual battle scenes and speeches.

Rey Moro participant labor included the following activities: 1) searching for materials to create props for the performance; 2) demarcating play spaces by spatially separating Christians and Moors across from each other in the battlefield; 3) stagemanagement play involving character assignment and the scaffolding of play moves and speeches; 4) enacting pre-battle challenges on stick horses; 5) stick fighting; and 6) speechmaking.

Speechmaking entailed two dimensions of children's performance competence. First, children had to demonstrate an ability to recite the co-occurring formal textual, prosodic, paralinguistic, and kinesic features that identified utterances to be a token of the type palabras - what I call royal speeches. Second, it was also an activity that afforded embellishment of the Desafío script. The formal and oftentimes highly formulaic textual properties of Rey Moro speeches facilitated memorization and recitation. The predictable sequence organization of speechmaking, moreover, afforded acts of bravado to emerge as child actors improvised and or innovated new insults. It was during the situated performances across speech chains where different voices could be heard - from the executive voice of stage-manager uttered outside the performance

${ }^{2}$ Authenticity only seemed to be an issue for the children when interloping youths or adults interrupted their play. I have recorded children's reactions to these interruptions, and the discussions serve to establish a protected child-centric performance sphere, where children's expertise mattered more in the production, reception, and evaluation of expressive forms. 
frame to the participatory, enregistered voices of royalty and subsequent hybrid personae emerging through speechmaking turns-at-talk.

\section{Voice and heteroglossia in Rey Moro performances}

Agha (2005) makes clear that a Bakhtinian dialogic approach does not treat social voices as a "unified phenomenon but a class of cases involving different degrees and varieties of "individuality," cued by different co-occurring signs" (2005: 39). Across a range of cases, there are degrees of transparency in the typification of represented voices. Agha provides an analytic framework for teasing apart the contrastive individuation of social voices. A difference in voice may be keyed by metrical contrasts in text segments, with the speaker being unspecified, but clearly different. Other contrasts do specify personae from highly specific biographic identities to a social characterization of voices identified by contrasts among person deixis in text segments or through the use of metalanguage (Agha 2003: 44). Absent in his discussion, however, is explicit attention to suprasegmentable features like prosodic and paralinguistic features that contribute to the contextualization of talk (Cook-Gumperz 1995; CookGumperz and Gumperz 1978). These features are especially evident in children and youth's socio-dramatic play (Goldman 1998; Cook-Gumperz 1995; Kyratzis 1999, 2007; Tetreault 2009).

Enregistered voices comprise one subclass of social voices, wherein linguistic registers entail stereotypical figures of personhood. There even may be cases of subclass overlap keyed by voicing contrasts ${ }^{3}$. Agha makes clear that register formation is a dynamic process; across a given societal context, those imagined to be exemplary figures of personhood change over time. The mechanism of speech register transmission is grounded in historically situated, oftentimes mass-mediated, speech events chained together across social networks. And though speech registers are presumed to be the socio-historical precipitate of actual community members' speech, ideologies of language are in play. Exemplary speakers of speech registers may be fetishized in modernist prescriptive language ideologies to actively construct and constrain real speakers' subject-positionalities (Agha 2003; Inoue 2006; Pujolar 2000). In other words, some enregistered voices are a rarified sociolinguistic invention of tradition (Hobsbawm and Ranger 1992), emerging from the activities of a diverse array of actors and agencies engaged in imagining a collectivity often in contrast to modernity's “other(s)”.

\subsection{Enregistered voices: Congruent role alignments and voicing contrasts across speech chains}

The enregistered voice of royalty in San Antonio and surrounding towns can be classified as a code-specific genre (Garrett 2005) as it usually emerged within Desafío and Rey Moro performances. I did hear, however, the enregistered voice of royalty invoked in specific instances of teasing and shaming between unequal peers who were not engaged in socio-dramatic play. In children's "reflexive typifications" of an

\footnotetext{
${ }^{3}$ Tetreault (2009), for example, examines how Muslim French teenagers key a performance framework to tease one another speaking in a standard variety of French associated with generic massmediated (game)show host-style; they even individuate specific host's host-style in their mocking.
} 
exemplary royal voice (Agha 2003), acoustic paralinguistic contextualization cues (Cook-Gumperz and Gumperz 1978) resembling the requisite raspy, tenor qualities of imagined royal voices indexed iconized qualities of hyper-masculinity (Irvine and Gal 2000). Interestingly there were no significant distinctions made between "good" king and "bad" king voices; a royal voice was simply a royal voice. Additional paralinguistic and prosodic cues produced highly stylized speech, especially during enactments of the dénouement to the performance articulated in the final leave-taking speech. Specifically, performers pronounced each syllable in staccato. Prosodic contextualization cues denoted discourse units. Penultimate syllables were marked with an increase of volume and sometimes elongated vowel, and then contrasted with dramatic falling contour on the last stressed syllable.

\section{(2) Written Text}

1 adiós Señor Esquipulas

2 adiós

\section{Performed Text}

1 a-dios-se-ñor-es-qui-P U

-l

a

2 A::-

d

ó

$\mathbf{S}$

In battle scenes, actors would thrust their swords with gusto as they uttered the penultimate syllable. Particular to interactions involving the sacred image, Señor Esquipulas (or Jesus), child actors would additionally brandish stick swords on the penultimate syllable of despedida speeches.

Three types of interactions involved the recitation of royal speeches and there was striking similarities across all three types to allow for mastery and embellishment. Participation frameworks in all of these kinds of royal speeches clearly demarcated discordant perspectives and by design, heightened differences in the moral logic articulated by each character. Each turn at talk was moreover part of a longer sequence of speech chains in collaborative speechmaking particular to the performance genre (Agha 2003). In these chains a child actor, while in character, would deliver a message normally in alignment and congruent with his/her character role. The following examination of royal voices and Rey Moro speeches reveals how these contrasting perspectives were enregistered as the stereotypical voices of kings and organized according to several formal and sequential properties of these types of speeches.

The first type of Rey Moro speech occurred only in play performances where many children were present. Someone would be assigned the role of messenger. One king would utter palabras to the messenger, ordering him or her to convey his message (usually a threat) to the opposing king. Interaction \#1 provides a representation of the participation framework, the performed text and the sequence organization typical of these interactions. 
(3)

Interaction \#1: Palabras to Messenger

$\begin{array}{lll}\text { Participation Frame } & \text { Palabras } & \frac{\text { Form, Function, \& }}{\text { Sequence Organization }} \\ \begin{array}{l}\text { Rey Cristiano } \rightarrow \text { Messenger; } \\ \text { [Messenger } \Rightarrow \text { Rey Moro] }\end{array} & \begin{array}{l}\text { Llamá tu rey } \\ \text { Notify your king } \\ \text { dentro de unas horas } \\ \text { within a few hours, } \\ \text { ya está muerto! } \\ \text { he'll already be dead! }\end{array} & \begin{array}{l}\text { Declarative - Threat } \\ {\left[\mathrm{FPP}_{2}\right]}\end{array} \\ & \end{array}$

The act characteristics and sequence organization of conjoined adjacency pairs (Schegloff and Sachs 1973) in a hypothetical interaction would include the following. Rey Cristiano issues a directive [first pair part ${ }_{1}$ ] and a threatening declarative statement [first pair part ${ }_{2}$ ], which the messenger complies with when he delivers [second pair part $_{1}$ ] the message [second pair part 2 ] to Rey Moro. In many of the actual performances, however, the messenger would not always have a chance to deliver the message. Excited by the unfolding action, the child actor representing the opposing king would not wait and immediately issue a counter threat.

The second type of speechmaking occurred during enactments of battle scenes. As the actors clashed swords, they simultaneously engaged in a verbal duel. Rey Moro often initiated these interactions by first threatening Rey Cristiano, who in turn would respond in kind. This dyadic participant framework can be decomposed further into a participant frame of paired counters (Goodwin 1990) wherein the sequences of turns could be recycled so that what the first speaker said is refuted and/or elaborated in someway through the use of format tying (Cf. Corsaro and Maynard 1996; Gossen 1976; Labov 1972; Mendoza-Denton 2008), often in the form of syntactic parallelism entailing a poetic level of discourse structure (Jakobson 1960; Silverstein 1993) ${ }^{4}$. Sawyer (1995: 141) has argued that the poetic structures of parallelism found in children's play operated as "meta-routines" are quite different from those described by Goodwin (1990). While that may be true for other play activities, in this particular type of Rey Moro speechmaking the meta-routine and paired counters are one in the same. In fact, paired counters can become quite elaborate and always follow the logic of chained sequences of adjacency pairs.

\section{(4) Interaction \#2: Royal speeches in paired counters}

$\frac{\text { Participant Frame: }}{\text { Paired Counters }}$
RM $\rightarrow$ RC
RC $\rightarrow$ RM

\begin{tabular}{|c|c|}
\hline Palabras & $\begin{array}{l}\text { Sequence } \\
\text { Organization }\end{array}$ \\
\hline $\begin{array}{l}\text { como soy un ma::lo. } \\
\text { As I am the bad guy }\end{array}$ & $\mathrm{FPP}_{1}$ \\
\hline $\begin{array}{l}\text { como yo soy un bueno } \\
\text { As I am the good guy }\end{array}$ & $\mathbf{S P P}_{2}$ \\
\hline
\end{tabular}

${ }^{4}$ Paired counters is but one type of discursive play framework that follows an embellishment-ofroutine pattern documented across a range of peer cultural contexts (Corsaro 1985; Fein 1987; Sawyer 2002; Sutton-Smith 1981). 


\section{I have a crown of (?) And Jesús has that love for me no a los malos \\ Not for the bad guys}

As the duel proceeded in this particular set of paired counters, each actor elaborated his character's respective position following the binary moral logic engendered in the Desafío script. The moral essences that child actors purported their characters to possess, however, was an emergent product of their own consciousness (Bauman 1984; Williams 1977).

The third and final type of interaction that the children consistently performed was the despedida (leave-taking or closing speech). Closing speeches also followed a dyadic participation frame wherein one of the interlocutors was an imaginary audience embodied in the sacred image representing God. These speeches were performed every time a king would directly address the image of the Almighty - Señor or Señor Esquipulas, the Black Christ.

The fact that the children of this network referred to Christ almost exclusively as the Black Christ indexes a local geography of overlapping municipal social alliances. This neighborhood block represented the boundary between the municipalities of San Antonio Aguas Calientes and Santa Catarina Barahona. Thus, the children in this peer network were audience to twice as many Desafío performances - the first of which were sponsored by the residents of Santa Catarina. In fact, Santa performances occurred right outside the walls of these children's households.

Despedida speeches most often took place when Rey Cristiano would swear to defend the Christian God, proving his allegiance by returning with a defeated Rey Moro. This happened periodically throughout play performance episodes. The final closing speeches mirrored Desafío speeches and occurred at the very end of the performance when Rey Cristiano presents the vanquished Moor. Rey Cristiano would first deliver his speech, which in turn was followed by Rey Moro's address. Interaction 3.1 and 3.2 illustrate tokens of typical Rey Cristiano and Rey Moro closing speeches.

\section{(5)}

\section{Interaction \#3.1: Rey Cristiano Despedida}

\section{Participation frame}

Rey Cristiano $\rightarrow$ Señor Esquipulas $\underline{\text { Palabras }}$

1 Señor Esquipulas

2 aquí está lo que quería

here is what you wanted

3 adiós Señor Esquipulas goodbye Señor Esquipulas

4a ahorita te va hablar

he will speak to you

forthwith

4b nos vemos en la plaza

we will see each other in the plaza

\section{Sequence Organization Opening:}

1 Greeting

2 Stance (servant of God)

Closing:

3 Pre-closing

4 Pre-opening

vs.

Re-opening 


\section{5 adiós 5 Final closing \\ Goodbye}

Rey Cristiano initiates the despedida invoking the name of his addressee with a vocative. The enunciation of an honorific + address term in this context serves a phatic function to establish communication between two interlocutors (Jakobson 1960). Immediately afterwards, Rey Cristiano aligned with the sacred image and displayed a stance of "loyal servant to God". He declared that he has either complied with His wishes or that he was one among many who believe in Him. After this opening sequence, logically comes the closing sequence. It is initiated with a first despedida to Señor Esquipulas, immediately followed with a re-opening utterance that indicated a continuing relationship (represented in line $4 \mathrm{~b}$ as a future encounter in the plaza). In despedida speeches where Rey Cristiano presented the defeated Rey Moro to Señor Esquipulas, instead of a re-opening utterance, the actor pronounced a pre-opening utterance (represented in line 4a, ahorita te va a hablar), which served as introduction and notified Him that his speech would be followed by Rey Moro's closing speech. The closing sequence ended with a final closing.

Rey Moro closing speeches usually paralleled those of Rey Cristiano with the exception that this character never uttered a pre-opening sequence.

\section{(6) Interaction \#3.2: Rey Moro Despedida}

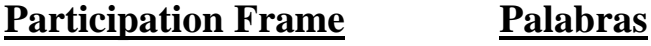

Rey Moro $\rightarrow$ Señor

Esquipulas $\begin{array}{ll}1 & \text { Señor Esquipulas } \\ 2 & \text { Le convence a todos } \\ \text { You convince everyone }\end{array}$

3 adiós Señor Esquipulas goodbye Señor Esquipulas

4 nos vemos en la plaza
we will see each other the plaza

5 adiós Señor Esquipulas goodbye Señor Esquipulas

\section{Sequence Organization} Opening:

1 Greeting

2 Stance (servant of God)

\section{Closing:}

3 Pre-closing

4 Re-opening

5 Closing

6 Final closing

The sequence organization of these highly routinized closing speeches were strategically exploited and embellished by the child actors to render an outcome dramatically different from Desafío performances. In this final analytic section, I examine how these co-constructed plot twists and hybrid personae sequentially emerged in non-congruent voicing contrasts as el Rey Moro refused to convert to Christianity during his closing speeches. 
4.2.1. Troping enregistered voices: Non-congruent voicing contrasts across speech chains as $n+1^{\text {st }}$ order indexicality

As the prior section underscored, core children in this peer network demonstrated considerable knowledge of the formal features of Desafío palabras. Their knowledge was in fact superior to that of most adults in the community. Communicative competence in speechmaking, however, was unequally distributed. Yet in spite of disparities between players, those who had not participated in prior enactments were socialized to and through speechmaking during the play performance itself (Reynolds 2010). Competent peers' extensive use of congruent voicing contrasts, when paired with new players' prior knowledge of el Desafío plot and episodic structure, helped to scaffold them into performance competence. Consequently, novice players quickly were able to improvise new speeches injecting unpredictable content into the genre. This in turn provided an opportunity for more seasoned players to further embellish and innovate royal palabras. In the following transcript excerpts (7-9), I examine how expert speechmaker Pedrito (age six), and novice, Élfido (age 11), staged a highly elaborated Rey Moro performance. It is within this highly contingent, collaborative event that these children appropriated el Desafío and re-accented it with their own perspectives reflecting an age-graded, generational structure of feeling.

The first transcript excerpt exemplifies a highly hybridized episode of Rey Moro play. The two actors, Pedrito (as Rey Cristiano) and Élfido (as Rey Moro), were engaged in a physical duel, a battle scene between kings. Rey Cristiano recited a leavetaking speech during the heat of battle instead of initiating a verbal duel (7, lines 2-5). The speech reiterated his political and religious stance of faithful servant of God and it provided an opportunity for Rey Moro to counterpoise. However, Élfido did not respond quickly enough to suit Pedrito. Pedrito quickly shifted between in- and out-ofplay frames via a congruent voicing contrast (7, beginning in line 6) in order to prompt Élfido to improvise a speech of paired counters during the dueling sequence (See example 4, interaction type two).

Pedrito often uttered features of a caregiver register (bald directives, shaming routines, and false threats) during stage-managing speech (Hoyle 1998; Wolf and Hicks 1989) to direct socio-dramatic actions with less competent players (Reynolds 2010). He conjugated the Spanish verb hablar 'to speak' with the imperative form + the $2^{\text {nd }}$ person familiar, vos (T-form). Then during subsequent turns at talk, when Élfido still refused to comply with the command, Pedrito aggravated the command via a shift in prosodic contour (line 8), the use of a slang address term (line 10) and incremental increases in volume (lines $8,10,12$ ).

\section{Participants:}

RM (Rey Moro = Élfido)

RC (Rey Cristiano = Pedrito $)$

\section{L\# Participant; Utterance/Action English translation \\ $1 \quad$ ((The boys begin a sword \\ fight))}




\section{RC; Señor Esquipulas}

hh me me (convences) en la (plahh)

$4 \quad$ hh adiós Señor Esquihhepula

5 a:dio .hh

6 Pe; hablá.

$7 \quad$ (pause)

8 Pe; hablá::?

$9 \quad$ ((The boys circle each other as they sword fight, but Élfido does not begin his speech))

10 Pe; HABLÁ HOMBRE

11 Él; ((Élfido smiles at the CAM, but says nothing))

12 Pe; lo que dije yo::.:

13 Él; qué dijiste

14 Pe; lo que di- vos hablás cualquiera palabra .hh

[ya nos va

16 RM; [te vo::y a matar.

17 RC; yo te voy hacer un buen caldazo.

18

19

20 co::n eh en frente de Je::sus. yahh. ((the duel continues))

\section{Señor Esquipulas}

hh (You convince) me- me in the plahhh

hh goodbye Señor Esquipulas

goodbye .hh

speak.

spea::k

SPEAK MAN

what I told you.

what did you say?

What I said- you speak whatever word .hh

[We're going already.

[I'm going to kill you.

I'm going to turn you to mush.

wi:th eh in front of Jesus.

Right now. ${ }^{5}$

Only when Pedrito realized that Élfido might be lacking knowledge of what to say did he try a different strategy. He prompted Élfido to animate one of his prior turns at talk (7, line 12), but Pedrito's response was sufficiently vague that Élfido still did not know what to say (7, line 13). Pedrito started to tell him, but then self-interrupted; he simply told Élfido to say anything he liked (7, line 14). This was an unusual move for Pedrito who was accustomed to authoring speeches for younger players during other Rey Moro performances when he had to prompt them their lines (Reynolds 2010). Pedrito's refusal to speak for Élfido suggests that he was confident in Élfido's communicative competence to improvise. In fact, when Élfido first arrived, Pedrito predicted that their performance would be especially good that day since 'Élfido indeed knows the words' ("Élfido sí sabe las palabras"). This behavior also informs another dimension of the boys' relationship where a relative age hierarchy was provisionally subverted. Pedrito was the younger of the two; his expertise afforded him the authority to direct, but not determine Élfido's subsequent play moves. Élfido finally complied when he switched back into the play frame, assumed the voice of Rey Moro and issued an appropriate threat in the form of a declarative statement forecasting action, 'I'm going to kill you' (7, line 16). Rey Cristiano followed in kind with a threat of his own, but in this case there were tropic effects.

\footnotetext{
${ }^{5}$ This utterance is also an affective 'sound effect', to accompany the clashing sword attack.
} 
Up until this point all of the voicing contrasts represented here are examples of free direct speech, formally characterized as metrically contrastive text segments that differ in indexical/deictic origo (they are spoken by different child actors). Rey Cristiano's utterance exemplified in line 17 does not explicitly indicate a different deictic origo, but rather the indexical form entailed a competing structure of value. This is what Silverstein (2003) has referred to as the dialectics of orders of indexicality realized in micro-real time when an indexical form is conceptualized simultaneously as indexicality of the $n$th order and the $n+1$ st order (Silverstein 2003: 194). Pedrito's incharacter voicing contrast articulated in line 17 was an unrestrained voice of caregiving, a false threat to discipline naughty charges ${ }^{6}$. In fact, I routinely heard similar expressions "I'm going to turn you into (X type of food)" uttered by children in pretend play, enacting mother/father-daughter domestic sphere activities and by actual adult and child caregivers (Reynolds 2002). A grandmother from a different household directed it at her fraternal twin grandchildren when they would not heed her warning to stop playing in the street. Thus, Pedrito's voicing contrast, an instance of $n+1$ st order indexicality uttered as the stereotypical caregiver/near-peer - a form of recursive projection from one social domain to another (Irvine and Gal 2000), is a striking adoption of a real world authoritative stance not congruent with the propositional content typical of royal palabras ( $n$th order indexicality). When imaginary dueling kings threaten each other in the hybridized voice of real life caregivers, children tropically expanded the social range of persona who speak with moral authority, something that was not permitted within the adult genre. Thus, while the voicing contrast is not expressly subversive in terms of the content that is introduced, its indexical entailment is subversive; the carnivalesque is smuggled in via the voicing contrast.

4.2.2. Troping enregistered voices: Embellishing non-congruent voicing contrasts across speech chains

The second transcript excerpt represents the boys engaged in a full performance mode. I argue that it reveals their unique positionality as child actors (rather than teen actors or adult actors). Voicing contrasts are apparent as the boys continued to make use of format tying (8, line 5) and formulaic text segments of a now enregistered caregiver discourse infused royal speeches with additional tropic effects (8, lines 17 and 18).

\section{(8) Excerpt \#2}

Participants:

RM (Rey Moro = Élfido $)$

RC (Rey Cristiano = Pedrito)

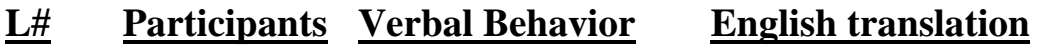

$1 \quad$ ((The boys resume play and

begin to enact a sword fight))

\footnotetext{
${ }^{6}$ Other studies of girls' peer group pretend role-play in the United States and Great Britain have found that the stereotypical voice of mother (the primary caregiver) is often realized via bald imperative utterances (Cook-Gumperz 1995; Kyratzis et al. 2001).
} 


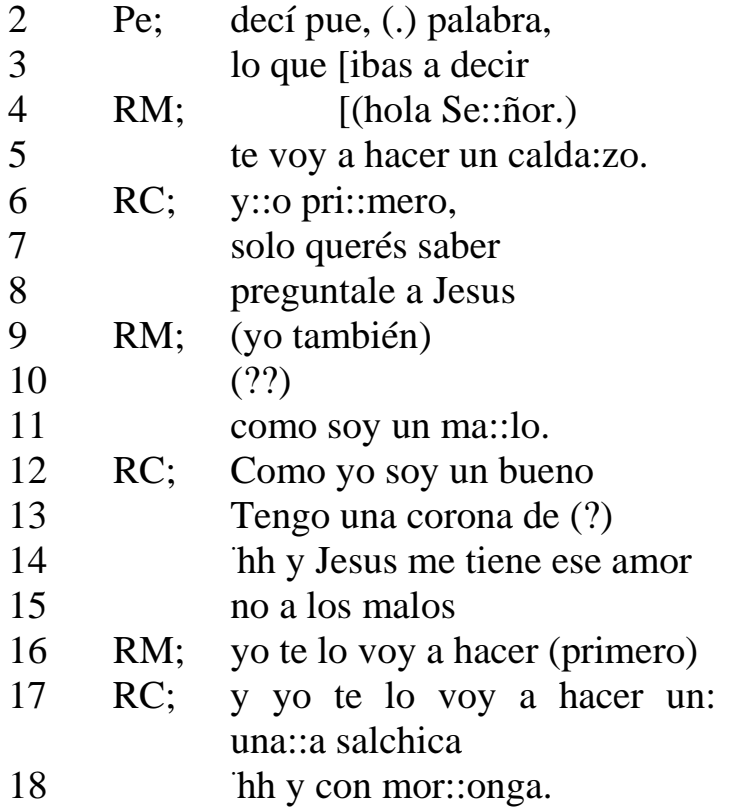

say it (.) speech, what [you] [were going to say [(hello Señor)

I'm going to turn you to mu:sh.

M::e fir::st

only [that what] you want to know ask Jesus

(Me too)

(??)

As I am a bad guy.

As I am a good guy

I have a crown of (?)

hh and Jesus has that love for me

not for the bad guys.

I am going to turn you (first)

And I am going to turn you into a:: hotdog

hh along with bloo::d sausage.

Élfido, in overlap with Pedrito's out-of-character prompt, uttered his first Rey Moro palabras in line 4. He issued a greeting, but the referent is ambiguous; it was most likely Christ as Señor was the honorific consistently used to refer to Christ. The actions, however, indicated that the scene is the staged battle between kings. In this sense, Élfido blurred the goodbye speech with the verbal duel format when he threatens Him in line 5, 'I'm going to turn you to mush' (literally, 'I'm going to make you into soup'). This was an entextualizing move; one that appropriated Pedrito's enregistered innovation (7, line 17), format tying this new battle scene back to the previous one. Rey Cristiano then regained the floor, invoking a formulaic turn taking device in these speeches (8, line 6). He reflected the threat back at Rey Moro, claiming that no, he will turn Rey Moro to mush first, which is then followed by typical proselytizing discourse (lines 7-8).

The next set of paired speeches illustrates a consensus between actors on the dichotomized moral positioning of their characters. Rey Cristiano's speech paralleled that of Rey Moro's (8, line 11), positioning him as the self-proclaimed hero (8, line 12). The hero could be identified by his crown (8, line 13) and by the fact that Jesus had love only for him (8, line 14). The palabras from line 14 contrasted with those in the subsequent utterance (8, line 15), they indicated Jesus' refusal to love immoral villains. In line 16 Rey Moro reissued his threat (or perhaps a second threat), which Rey Cristiano immediately countered (lines 17 and 18). In fact, Rey Cristiano verbally intensified the duel when he declared that not only would he make Rey Moro into a hotdog, but a blood sausage as well. To wit, 'not only are you dead meat, but two kinds of dead meat'! The tropic voicing contrast within this second type of Rey Moro speechmaking most resembles peers' rough verbal play in contests of wit ${ }^{7}$. After this final threat, it was clear that Rey Cristiano had outmaneuvered Rey Moro with his superior speechmaking and sword fighting skills. The battle scene ended with Rey

\footnotetext{
${ }^{7}$ It is not surprising that I witnessed leakage of voicing contrast across different types of playframes. Pedrito would speak as Rey Cristiano to shame a 19-year-old rival peer who worked in the household adjacent to ours, just as the voice of caregiving infused the enregistered voice of royalty.
} 
Cristiano, temporarily the victor. The boys dropped out of play frame to transition to a different socio-dramatic act.

\subsection{Conflicting voices, desires, and endings}

The third and final transcript excerpt (9) represents the final act of that day's Rey Moro performance, during which the boys simultaneously reconciled conflicts between personal desires and moral dilemmas. Their final leave taking speeches retain the enregistered and tropic voices of king and kin, a unique instantiation of the carnivalesque. And as will be revealed, the carnivalesque is especially apparent in the contrastive ending, where Rey Moro thwarts defeat. Oftentimes analyses of the carnivalesque emphasize parodic imitation, but the performance key in the boy's sociodramatic play remained earnest to the very end. In fact, they never explicitly engaged in parodic stylization to subvert sacred and secular moral authorities. In this way, my analysis of these children's performances differs from Bauman's (1996) findings on the emergence of an adult performer's parodic counterstatement evident in a series of rehearsals and 'official' performance of the coloquio, a Mexican Nativity play commonly performed in the ejido Tierra Blanca.

Earlier on that afternoon, an eavesdropping adult had interrupted their play. Élifdo's cousin, who had been spying through the cane wall, called him over to run an important errand. He was to deliver some raw black beans for his family's dinner. Élfido dutifully retrieved the beans, but then failed to complete the request. Instead, he returned to Pedrito's house to resume Rey Moro play. This unfulfilled responsibility was a subtext that explicitly surfaced in the boys' closing despedida speeches that transpired over an hour later and are represented in the final transcript excerpt.

Rey Moro challenged Rey Cristiano one last time to a sword fight and verbal duel performed in front of the processional image of Christ. The performance concluded with no clear victor. Rey Cristiano performed the loudest and most dramatic despedida speech from that afternoon. He first delivered Rey Moro to Señor Esquipulas and ordered him to confess that He gave him life (9, 3-4 lines). Rey Cristiano then took his leave, uttering the formulaic leave-taking sequence (9, lines 5-9). He then closed the play sequence by ordering Rey Moro/Élfido to deliver his beans while simultaneously inviting him to come and duel another day (9, lines 10-12). So this was not the end, but a new beginning. Pedrito's innovation was appropriately placed in the pre-opening sequence slot to secure Élfido's participation in future Rey Moro play performances.

\section{(9) Excerpt 3 - Final Closing Speeches}

1 RM; ((Rey Moro challenges Rey

$$
\text { Cristiano) })
$$

2 RC; ((RC turns, resumes the duel and begins his final speech)) 


7
8
9
10

11

12
13
14
15
16
17
18
19

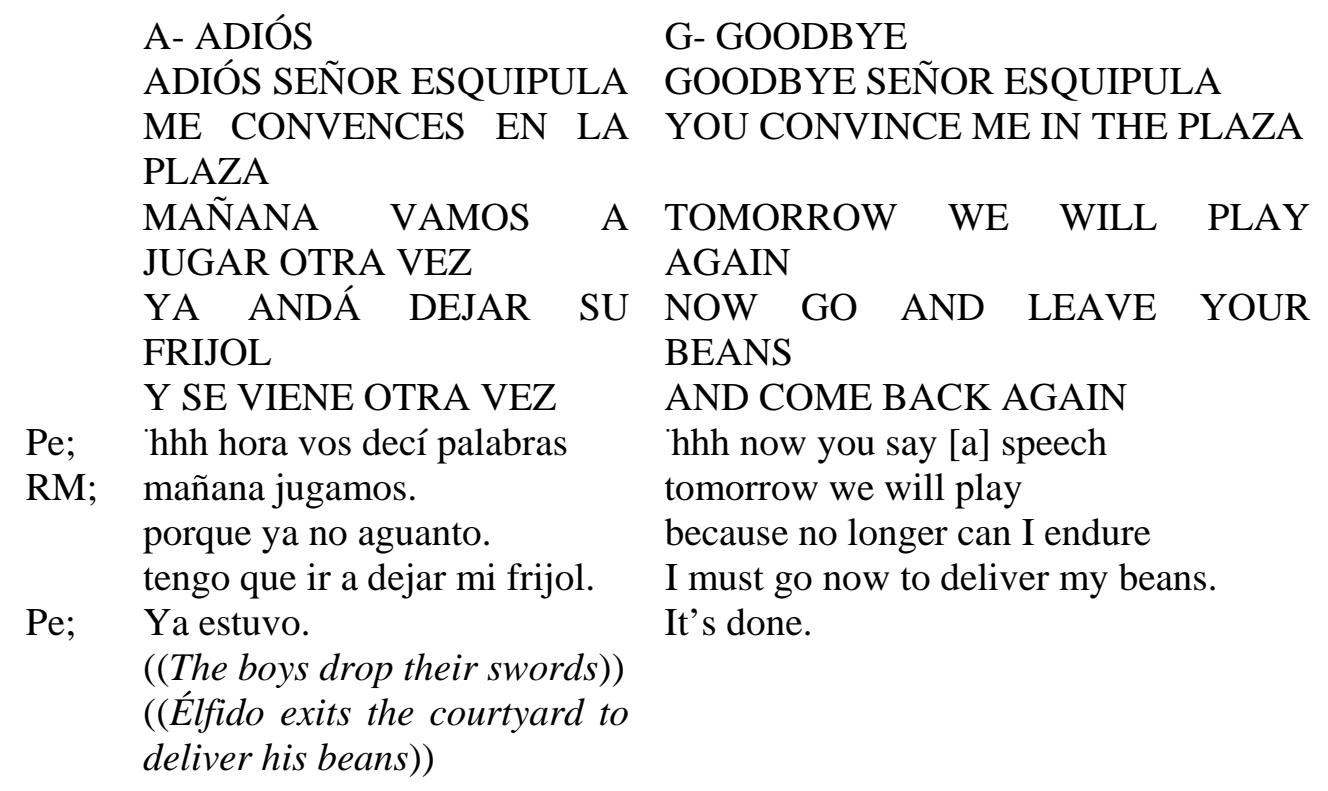

In line 14, Rey Moro accepted the invitation to play again. He admitted temporary defeat to Señor Esquipulas (line 15), but he did not display a moral transformation (he had not been convinced/converted in the plaza). Only in deference to familial responsibility must he desist. Thus, in Élfido’s/Rey Moro's final speech, he transformed himself from the "bad"/bold boy who refused to deliver the beans into the "good"/obedient boy who may now complete his errand. The play officially ends with Pedrito's closing utterance, 'it's done' in line 17. The boys dropped their swords and Élfido dashed off home with beans in hand to give to his mother.

\section{Discussion and conclusion}

In the early years of the post-civil war era, residents of San Antonio Aguas Calientes and the surrounding towns continued to imbue genres of reconquest with great sociocultural significance. For Pedrito's father, Don Gabriel, El Desafío 'the Challenge' served to remind him of his faith and stake an indigenous, collectivist claim to homeplace. The script and mythic-historical figures no longer served to legitimize a colonial order where Spanish conquistadores usurped indigenous land and slave labor for the good of the Crown and for building personal wealth.

Given that Guatemala as a whole, and San Antonio in particular, were just beginning to heal wounds inflicted by the political violence characterizing the late 1970s through early 1990s, an open assertion of positive indigenous selves must be considered a major social achievement (Cf. Offit and Cook 2010). However, it is a perspective that did not quite represent the up-coming generation's precarious position within Guatemala's neo-democratic, neoliberal order; some youth were hesitant to uncritically re-inscribe a patriarchal moral order, albeit inflected with indigenous authority. This hesitation was best articulated in the contingent performances of youth and young children who fixated on the Moorish King as someone who was "not convinced" of adult-centric moral orders. And so they engaged in their own spectacular displays of force made manifest as heteroglossic reflex. In closing this article, I recall an 
extensive passage from Sawyer (1995), wherein he first theorized a developmental model for peer-socialization to and through heteroglossic language in play.

Children's play may be a context for learning the voices and interactional genres that predominate in the culture. But more fundamentally, it seems that what children learn is how the different voices which compose a culture can interact, struggle, and be resolved in a fundamentally heteroglossic social environment; they learn how to "do heteroglossia" [...] The heteroglossic social encounter is the interactional space within which selves confront the social order, and within which both are continually created, through a process of improvisational interaction. (Sawyer 1995: 140-141)

I could not agree more. During Rey Moro socio-dramatic play performances, Antonero children, members of Pedrito Hernandez Pop's peer network, demonstrated their consciousness of several authoritative discourses that informed their lives. Specifically, they metapragmatically indexed moral, place-based, and caregiving discourses as they spoke in the enregistered voice of royalty.

To address Sawyer's first point, that children learn to do heteroglossia, my analysis reveals that the highly predictable formal properties and sequential organization served as a scaffolding mechanism and production format for innovation and improvisation during speechmaking. Both boys productively exploited prosodic, paralinguistic, and formulaic textual structures of these speeches. For example, all despedida speeches began with the opening ([greeting] + address term) to Señor Esquipulas and Rey Cristiano's speech included the closing, adiós. They also maintained parallel structures while issuing reciprocal threats: "te voy a hacer $+\ldots$... The prosodic and paralinguistic features were also vital in heightening the opposition of dueling voices with tropic effects. Finally, the performers not only adopted parallel structures internal to their speeches, but also they were careful to format tie subsequent utterances to prior speaker's speech. Thus, in example (8) excerpt \#2, lines 11-12, one actor ends his speech "como soy un malo" and the other format ties his new speech with the preface, "como soy un bueno", a recreation of the dichotomized moral worldview typical of adult Desafío performances, good versus evil and moral versus immoral.

In all of the observed instances of Rey Moro play, it was also clear that the fluidity of players and the varying degrees of communicative competence in some ways pre-empted the routinization or ritualization of routine (Iwamura 1980) of these sociodramatic performances, a phenomenon that can emerge within fixed peer group collaborations overtime. Thus, while the form of this genre superficially could exact a centripetal force delimiting what and how palabras could be delivered, the diversity of players across time and space enabled a centrifugal force to dynamically ensure that each performance was uniquely experienced.

Speechmaking, moreover, was the discursive vehicle through which children explored their multiple positionalities confronting the social order (Cf. García-Sánchez, this volume). In the performance examined here, Pedrito and Élfido's non-congruent employment of verbal threats "I'm gonna turn you into soup/hotdog/blood sausage" were not the threats used by adult performers in Desafio performances. Pedrito's innovation, when he uttered caregivers' false threats to control behavior deemed bad or inappropriate, provides evidence of the type of transformation that this performance genre has undergone. In other words, the tropic voicing effects of caregiver threats uttered as royal register were now directed at the anti-hero el Rey Moro. Children were 
exercising their relative position of power in fantasy play - much like Vygotsky (1967) early observed in play as scaffolding its own zone of proximal development.

Bauman and Briggs (1990) long ago argued that performers exploit performance to examine and relate otherwise separate social experiences. Here the children explored their unequal social positions as ones who are judged and evaluated by older caregivers. They are the ones whose abilities and responsibilities were highly scrutinized and determined to be moral or not. I suggest that these child actors through their performance drew an analogy between a caregiver (older near-peer and adult) speaker's secular authority to evaluate younger children's misbehavior and the sacred authority to pass judgment on the morality of one's divinely inspired deeds. After all, those deserving of Jesus' love in Rey Moro performances are "the good guys," not the "bad guys". Perhaps, even on an unconscious level, these boys may be exploring the extension of this analogy to their own lives, entertaining the possibility that caregivers' (and peers') support and love may also be withheld for acts of misbehavior.

Finally, in this particular work-in-progress, Pedrito and Élfido always singled out $e l$ Moro for special attention, and they threatened his very existence using the same false threats that kin caregivers uttered when scolding them for bold behavior. During the highly embellished play performance examined here, the character, Rey Moro, determined when he would be vanquished. It did not matter how many times Rey Cristiano out-maneuvered him in battle and prostrated him in front of Señor Esquipulas; Rey Moro decided if and when to conform to the moral authority's wishes. He decided when he would desist resisting Jesus' words (in order to deliver his beans) and when he would return to play and turn Rey Cristiano into caldazo (mush). In fact in the final closing speech, Rey Moro resisted conversion. The figure of the Moor enabled these peer practices of pleasure and power in an examination of the "symbolism of their subordination” (Warren 1978).

\section{Acknowledgements}

The research reported here was supported by grants from The Wenner-Gren Foundation and the Department of Anthropology at University California, Los Angeles. I would like to acknowledge the support and input of my colleagues Alessandro Duranti, Lourdes de León, Ann-Carita Evaldsson, Brigittine French, Paul V. Kroskrity, Amy Kyratzis, Marjorie Goodwin, and Marjorie Faulstich Orellana, and three anonymous reviewers. A special thank-you is due the children of San Antonio Aguas Calientes who allowed me to be a respectful audience to their play performances.

\section{References}

Annis, Sheldon (1987) God and production in a Guatemalan town. Austin: University of Texas Press.

Agha, Asif (2003) The social life of cultural value. Language and communication 23: 231-273.

Agha, Asif (2005) Voice, footing, enregisterment. Journal of linguistic anthropology 15: 38-59.

Bakhtin, Mikhail M. (1981) The dialogic imagination. Austin: University of Texas Press. 
Bakhtin, Mikhail M. (1984) Rabelais and his world. Bloomington: Indiana University Press.

Bateson, Gregory (1972) Steps to an ecology of mind. New York: Ballantine.

Bauman, Richard (1982) Ethnography of children's folklore. In Perry Gilmore and Allan A. Glatthorn (eds.), Children in and out of school: Ethnography and education. Washington, D.C.: Center for Applied Linguistics, pp. 172-186.

Bauman, Richard (1984) Verbal art as performance. Prospect Heights, Illinois: Waveland Press, Inc.

Bauman, Richard (1996) Transformations of the word in the production of Mexican festival drama. In Michael Silverstein and Greg Urban (eds.), Natural histories of discourse. Chicago: The University of Chicago Press, pp. 301-327.

Bauman, Richard (2001) The ethnography of genre in a Mexican market: Form, function, variation. In Penelope Eckert and John Rickford (eds.), Style and sociolinguistic variation. New York: Cambridge University Press, pp. 57-77.

Bauman, Richard, and Charles L. Briggs (1990) Poetics and performance as critical perspectives on language and social life. Annual review of anthropology 19: 59-88.

Bricker, Victoria Reifler (1973) Ritual humor in highland Chiapas. Austin: University of Texas Press.

Brown, R. McKenna (1998) Case study two: San Antonio Aguas Calientes and Quinizilapa Valley. In Susan Garzon, R. McKenna Brown, Julia Becker Richards, and Wuqu’ Ajpub’ (Arnulfo Simón) (eds.), The life of our language: Kaqchikel Maya maintenance, shift, and revitalization. Austin: University of Texas Press, pp. 101-128.

Canclini, Néstor García (1995) Hybrid cultures: Strategies for entering and leaving modernity. Minneapolis: University of Minnesota Press.

Castañeda, Quetzil E. (1996) In the museum of Maya culture: Touring Chichén Itzá. Minneapolis: University of Minnesota Press.

Casaus Arzú, Marta Elena (1992) Guatemala: Linaje y racismo. San José, Costa Rica: Facultad Latinoamericana de Ciencias Sociales.

Cook-Gumperz, Jenny (1995) Reproducing the discourse of mothering: How gendered talk makes gendered lives. In Kira Hall and Mary Bucholtz (eds.), Gender articulated: Language and the socially constructed self. New York: Routledge, pp. 401-420.

Cook-Gumperz, Jenny, and John J. Gumperz (1978) Context in children’s speech. In Natalie Waterson and Catherine Snow (eds.), The Development of Communication. New York: Wiley, pp. 3-23.

Corsaro, William A. (1985) Friendship and peer culture in the early years. Norwood, NJ: Ablex Publishing Corp.

Corsaro, William, and Doug W. Maynard (1996) Format tying in discussion and argumentation among Italian and American children. In Dan I. Slobin, J. Gerhardt, Amy Kyratzis, and J. Guo (eds.), Social interaction, social context, and language. Mahwah, NJ: Lawrence Erlbaum Associates, pp. 157-74.

de León, Lourdes (2006) Ritual, humor, fantasía y relato: Desarrollo de competencias comunicativas en niños tzotziles de Zinacantán. Plenary Lecture. VIII Jornadas Lingüísticas de la Escuela Nacional de Antropología e Historia. México, D. F. April 2006.

de León, Lourdes (2007) Parallelism, metalinguistic play, and the interactive emergence of Zinacantec Mayan sibling's culture. Research on language and social interaction 40.4: 405-436. 
Ervin-Tripp, Susan (1977) Wait for me, roller skate! In Susan Ervin-Tripp and Claudia Mitchell-Kernan (eds.), Child discourse. New York: Academic Press, pp. 165-188.

Evaldsson, Ann-Carita, and Asta Cekaite (this volume) “'Schwedis’ he can’t say Swedish”: Subverting and reproducing institutionalized norms for language use in multilingual peer groups. Pragmatics 20.4.

Fein, Greta (1987) Pretend play: Creativity and consciousness. In D. Gorlitz \& J.F. Wohlwill (eds.), Curiosity, imagination, and play: On development of spontaneous cognitive and motivational processes. New York: Oxford, pp. 82-94.

Ferguson, Charles A. (1994) Dialect, register, and genre: Working assumptions about conventionalization. In Douglas Biber and Edward Finegan (eds.), Sociolinguistic perspectives on register. New York and Oxford: Oxford University Press, pp. 15-30.

Flores, Richard R. (1994) “Los pastores” and the gifting of performance. American ethnologist 21.2: 270285.

French, Brigittine (2010) Mayan ethnolinguistic identity: Violence, cultural rights, and modernity in highland Guatemala. Tuscon: University of Arizona Press.

García-Sánchez, Inmaculada M. (this volume) Series games: Code-switching and gendered identities in Moroccan immigrant girls’ pretend play. Pragmatics 20.4.

Garrett, Paul B. (2005) What a language is good for: Language socialization, language shift, and the persistence of code-specific genres in St. Lucia. Language in society 34: 327-361.

Gaskins, Suzanne (2006) The cultural organization of Yucatec children's social interactions. In X. Chen, D. French, and B. Schneider (eds.), Peer relations in cultural context. Cambridge: Cambridge University Press, pp. 283-309.

Glick Schiller, Nina (2003) The centrality of ethnography in the study of transnational migration: Seeing the wetlands instead of the swamp. In Nancy Foner (ed.), American arrivals: Anthropology engages the new immigration. Santa Fe: School of American Research, pp. 99-128.

Goldman, L.R. (1998) Child's play: Myth, mimesis and make-believe. Oxford and New York: Berg.

Goldstein, Daniel M. (2004) The spectacular city: Violence and performance in urban Bolivia. Durham: Duke University Press.

Goodwin, Marjorie Harness (1990) He-said-she-said: Talk as social organization among Black children. Bloomington: Indiana University Press.

Gossen, Gary (1976) Verbal dueling in Chamula. In Barbara Kirshenblatt-Gimblett (ed.), Speech play: Research and resources for studying linguistic creativity. Philadelphia: University of Pennsylvania Press, pp. 121-146.

Harris, Max (2000) Aztecs, Moors and Christians: Festivals of reconquest in Mexico and Spain. Austin: University of Texas Press.

Hill, Jane (1998) “Today there is no respect": Nostalgia, "respect”, and oppositional discourse in Mexicano (Nahuatl) language ideology. In Bambi B. Schieffelin, Kathryn A. Woolard, and Paul V. Kroskrity (eds.), Language ideologies: Practice and theory. New York: Oxford University Press, pp.6886.

Hobsbawm, Eric, and Terence Ranger (1992) The invention of tradition. Cambridge: Cambridge University Press. 
Hoyle, Susan M. (1993) Participation frameworks in sportscasting play: Imaginary and literal footings. In Deborah Tannen (ed.), Framing in discourse. New York and Oxford: Oxford University Press, pp. 114145.

Hoyle, Susan M. (1998) Register and footing in role play. In Susan M. Hoyle and Carolyn Temple Adger (eds.), Kids talk: Strategic language use in later childhood. New York and Oxford: Oxford University Press, pp. 47-67.

Inoue, Miyako (2006) Vicarious language: Gender and linguistic modernity in Japan. Berkeley and Los Angeles: University of California Press.

Irvine, Judith T., and Susan Gal (2000) Language ideology and linguistic differentiation. In Paul V. Kroskrity (ed.), Regimes of language: Ideologies, polities, and identities. Santa Fe: School of American Research, pp. 35-83.

Iwamura, Susan G. (1980) The verbal games of preschool children. New York: St. Martin’s Press.

Jakobson, Roman (1960) Closing statement, linguistics and poetics. In T. Sebeok (ed.), Style in language. Cambridge, Mass.: MIT Press, pp. 398-429.

Kearney, Michael (2000) Class and identity: The jujitsu of domination and resistance in Oaxacalifornia. In Dorothy Holland and Jean Lave (eds.), History in person: Enduring struggles, contentious practice, intimate identities. Santa Fé, NM: School of American Research Press, pp. 247-280.

Kroskrity, Paul V. (2000) Regimenting languages: Language ideological perspectives. In Paul V. Kroskrity (ed.), Regimes of language: Ideologies, polities, and identities. Santa Fe: School of American Research, pp. 1-34.

Kyratzis, Amy (1999) Narrative identity in preschool same-sex friendship groups: Fluidity over time and context. Narrative inquiry 9: 427-455.

Kyratzis, Amy (2007) Using the social organizational affordances of role playing in American preschool girls’ interactions. Research on language and social interaction 40: 321-352.

Kyratzis, Amy (this volume) Latino girls' peer play interactions in a bilingual Spanish-English US preschool: Heteroglossia, frame-shifting, and language ideology. Pragmatics 20.4.

Kyratzis, Amy, T. Marx, and E.R. Wade (2001) Preschoolers' communicative competence: Register shift in the marking of power in different contexts of friendship group talk. In H. Marcos (ed.), Early pragmatic development (spec. issue). First language 21: 387-431.

Labov, William (1972) Rules for ritual insults. In David Sudnow (ed.), Studies in social interaction. New York: Free Press, pp. 120-169.

Limón, José E. (1983) Western Marxism and folklore: A critical introduction. The journal of American folklore 96.379: 34-52.

Mendoza-Denton, Norma (2008) Homegirls: Language and cultural practice among Latina youth gangs. Malden, MA: Blackwell Publishing.

Minks, Amanda (2008) Performing gender in song games among Nicaraguan Miskitu children. Language and communication 23.1: 36-56.

Minks, Amanda (this volume) Socializing heteroglossia among Miskitu children on the Caribbean coast of Nicaragua. Pragmatics 20.4 .

Nagengast, Carole, and Michael Kearney (1990) Mixtec ethnicity: Social identity, political consciousness, and political activism. Latin American research review 25: 61-91. 
Nájera-Ramírez, Olga (1999) Of fieldwork, folklore, and festival: Personal encounters. The journal of American folklore 112.444: 183-199.

Nash, June (1970) In the eyes of the ancestors. Belmont, CA: Wadsworth Group.

Ochs, Elinor (1992) Indexing gender. In Alessandro Duranti and Charles Goodwin (eds.), Rethinking context: Language as interactive phenomenon. Cambridge: Cambridge University Press, pp. 335-358.

Offit, Thomas A., and Garrett Cook (2010) The death of don Pedro: Insecurity and cultural continuity in peacetime Guatemala. The journal of Latin American and Caribbean anthropology 15.1: 42-65.

Paugh, Amy L. (2005) Multilingual play: Children's codeswitching, role play, and agency in Dominica, West Indies. Language in society 34.1: 63-86.

Porrúa, Miguel Angel (ed.) (1994) Los doce pares de Francia: Historia para teatro campesino en tres noches. Morelos: Gobierno del Estado.

Pujolar, Joan (2000) Gender, heteroglossia and power: A sociolinguistic study of youth culture. Berlin and New York: Mouton de Gruyter.

Reynolds, Jennifer F. (2002) Maya children's practices of the imagination: (Dis)Playing childhood and politics in Guatemala. Ph.D. dissertation, Department of Anthropology, University of California, Los Angeles.

Reynolds, Jennifer F. (2008) Socializing puros pericos (little parrots): The negotiation of respect and responsibility in Antonero sibling and peer networks. Journal of linguistic anthropology 18.1: 82-107.

Reynolds, Jennifer F. (2009) Shaming the shift generation: Intersecting ideologies of family and linguistic revitalization in Guatemala. In Paul V. Kroskrity and Margaret C. Field (eds.), Revealing Native American Language Ideologies: Beliefs, Practices, and Struggles in Indian Country. Tuscon: University of Arizona Press, pp. 213-308.

Reynolds, Jennifer F. (2010) La socialización del lenguaje entre grupos de pares: La elicitación de contribuciones en el juego de el Rey Moro. In Lourdes de León, (ed.), Lenguajes y culturas infantiles: Estudios transculturales sobre socialización y aprendizaje. México: CIESAS, pp. 355-387.

Rogers, Mark (1999) Spectacular bodies: Folklorization and the politics of identity in Ecuadorian beauty pagents. Journal of Latin American anthropology 3: 54-85.

Rogoff, Barbara (1981) Adults and peers as agents of socialization: A highland Guatemalan profile. Ethos 9.1: 18-36.

Rogoff, Barbara (2003) The cultural nature of human development. Oxford: Oxford University Press.

Rouse, Roger (1991) Mexican migration and the social space of postmodernism. Diaspora 1: 8-23.

Sawyer, R. Keith (1995) A developmental model of heteroglossic improvisation in children's fantasy play. Sociological studies of children 7: 127-153.

Sawyer, R. Keith (2001) Play as improvisational rehearsal: Multiple levels of analysis in children's play. In Artin Göncü and Elisa Klein (eds.), Children in play, story and school. New York: Guilford Press, pp. 19-38.

Sawyer, R. Keith (2002) Improvisation and narrative. Narrative inquiry 12.2: 319-349. 
Sawyer, R. Keith (2003) Levels of analysis in pretend play discourse: Metacommunication in conversational routines. In Donald E. Lytle (ed.), Play and educational theory and practice. Westport, Conn.: Praeger, pp. 137-157.

Schegloff, Emmanuel A., and Harvey Sachs (1973) Opening up closings. Semiotica 8: 289-327.

Silverstein, Michael (1993) Metapragmatic discourse and metapragmatic function. In John A. Lucy (ed.), Reflexive Language. Cambridge: Cambridge University Press, pp. 33-58.

Silverstein, Michael (2003) Indexical order and the dialectics of sociolinguistic life. Language and communication 23: 193-229.

Steck, Francis Borgia (1951) Motolinia's history of the Indians of New Spain. Washington: Academy of American Franciscan History.

Sutton-Smith, Brian (1981) The folkstories of children. Philadelphia: University of Pennsylvania Press.

Tetreault, Chantal (2009) Mocking in mock French: Social uses of stylized voicing by Muslim French teenagers. Language in society 38: 201-231.

Vygotsky, Lev S. (1967) Play and its role in the mental development of the child. Soviet Psychology Vol. V. No. 3: 6-18.

Warren, Kay (1978) The symbolism of subordination: Indian identity in a Guatemalan town. Austin: University of Texas Press.

Warren, Kay B. (1998) Indigenous movements and their critics: Pan-Maya activism in Guatemala. Princeton: Princeton University Press.

Williams, Raymond (1977) Marxism and literature. Oxford: Oxford University Press.

Wolf, Dennie, and Deborah Hicks (1989) The voices within narratives: The development of intertextuality in young children's stories. Discourse processes 12: 329-351.

\section{Appendix}

\section{Transcription Key}

Transcripts are organized in columns (from left to right) and sequentially (from top to bottom). Information indicated within each line number cooccur and include the pseudonym of the social actor, his/her utterance with supersegmentable features (verbal behavior), and any 'action' (non-verbal behavior). Actions include what participants do (activities). The English gloss either appears in a different font directly underneath the utterance; in extended transcripts it appears in the far right hand column.

$$
\text { social actor }
$$

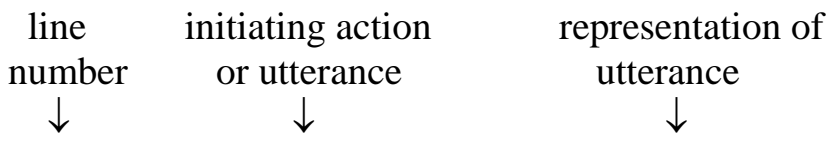

L\# $\quad$ Participants

1 Quique;

2

Pedrito;

\section{Verbal Behavior} vos Pedrito!

qué? gloss

\section{English Translation} you, Pedrito

what? 


\section{Orthographic conventions}

I use Spanish orthography and diacritic system (á, í, é, ó, ú, ü, ñ) with some minor modifications to indicate spoken words.

\section{Transcription Symbols [Modified from those originally devised by Gail Jefferson] \\ Symbol \\ Phenomena it represents}

-

?

,

[

$-$

(.)

(pause)

:

$\underline{\text { Line }}$

HEY

hh

.hh

((He smiles))

( )
A period indicates a falling intonation contour.

A question mark indicates a rising intonation contour.

A comma indicates a rising-falling intonation contour.

A bracket indicates overlapping talk.

A hyphen indicates a self-cut off or interruption; a speaker interrupts or cuts off his/her own talk.

A period inserted between parentheses indicates a micro pause.

This indicates a pause in talk or the activity.

A colon indicates sound stretches. Prolonged sounds are marked with many colons.

Underlined words indicate slightly increased volume

ALL CAPS indicate very loud volume

This indicates an audible in-breath.

This indicates an audible exhale.

Words appearing italicized between double parenthesis indicate non-verbal action.

Enclosed items between single parentheses indicate talk difficult to discern on the original tape.

JENNIFER F. REYNOLDS is an associate professor of anthropology at The University of South Carolina and a core member of Latin American, Latino/a, and Caribbean Studies and the interdepartmental program in Linguistics. She is a linguistic anthropologist who examines the relationship(s) between discursive practices and language ideologies as they are manifest in everyday life. She explores how children and youth experience and interpret the multiple dimensions of social inequality that shape their lives and pathways. Recent major publications: "Socializing puros pericos: The negotiation of respect and responsibility in Antonero Mayan sibling and peer networks” in the Journal of Linguistic Anthropology; "Shaming the shift generation: Intersecting ideologies of family and linguistic revitalization in Guatemala” in Revealing Native American Language Ideologies: Beliefs, Practices, and Struggles in Indian Country; and "New Immigrant youth interpreting in White public space" with Marjorie Faulstich Orellana in American Anthropologist.

Address: Department of Anthropology, The University of South Carolina, Hamilton College, Room 317, Columbia, SC 29208, United States. E-mail: jreynold@mailbox.sc.edu 